Ann. Génét. Sél. anim., 1976, 8 (3), 421-426.

\title{
SEX-LINKAGE AS A FACTOR \\ IN THE INHERITANCE OF SEX DIFFERENCES FOR BODY WEIGHT IN TWO STRAINS OF CHICKENS
}

\author{
H. AYOUB and M. MAGRABY* \\ Faculty of Agriculture, \\ Ain-Shams University, \\ Cairo (Egypt) \\ * Animal Production Department, \\ Ministry of Agriculture, \\ Cairo (Egypt)
}

\section{SUMMARY}

The interactions " sex $\times$ Sire families " and "sex $\times$ dam within Sire families " in two strains of chickens, Dokki-4 and White Plymouth Rock, were studied for body weight at 6 and 8 weeks of age. The results showed that Sire $\times$ sex interactions were not significant $(P>0.05)$ in all cases, but dam families within Sire $\times$ sex interactions were significant $(\mathrm{P}<0.05)$ in three cases out of four. The interaction between dam families and sex for $P l y$ mouth Rock was not significant $(P>0.05)$ at 8 weeks of age. The effect of sex-linked genes and the low magnitude of heritability of sex-differences were discussed.

\section{INTRODUCTION}

Many investigators showed evidence of the importance of sex-linkage in the inheritance of quantitative characters and some concluded that its effects are too great to be ignored for maximum efficiency in breeding, BEIL,HARZ (1962).

With respect to the phenomenon of sexual dimorphism in poultry, only researches proved the superiority of selection based on dam families over that based on sire families, SHAKLEE et al. (I952), Ayoub and MÉrRat (r972).

BEILHARZ (I960) explained the results of SHAKLEE et al. (I952), by the fact that cocks generally distribute identical sex chromosomes as well as autosomal chromosomes to offsprings, while dams (being $\mathrm{X}$-) distribute their sex chromosomes in different manner. This reason may be the cause of the low estimates of heritabilities for body weight differences found by AyouB and MAGRABY (I975), as the method 
suggested by KINNEY and SHOFFNER (I965) for the estimates of $h^{2}(1-2)$ ) gives only estimates based on sire components of variance. The present work therefore was designed to test the interaction "sex $\times$ sire families " and " sex $\times$ dams within sire families " in two strains of chicken in order to detect the effect of sex-linkage in the inheritance of sex differences.

\section{MATERIAL AND METHODS}

Two strains of chickens, namely Dokki $i_{4}$ and White Plymouth Rock, were used in this study. Data on body weight at 6 and 8 weeks of age were analysed using the unequal number model described by SNEDECOR and COCHRAN (1967).

\section{RESULTS}

\section{Differences between Sire families}

For $D_{o k k i_{4}}$ strain (table I) highly significant differences in body weight at 6 and 8 weeks of age were observed between both sexes, and sires families, However the sire $\times$ sex interaction was insignificant at the same ages.

TABLE I

Analysis of variance of body weight at 6 and 8 weeks of age using sire families for Dokki $_{4}$ strain

Analyse de variance du poids corporel à 6 et 8 semaines d'âge sur les familles de père pour la lignée $\mathrm{Dokki}_{4}$

\begin{tabular}{|c|c|c|c|c|}
\hline $\begin{array}{l}\text { Age in } \\
\text { weeks }\end{array}$ & S.V. & d.f. & Ms. & $\mathrm{F}$ \\
\hline 6 & $\begin{array}{l}\text { Between sexes } \\
\text { Between sires } \\
\text { Sire } \times \text { sex } \\
\text { Interaction } \\
\text { Residual }\end{array}$ & $\begin{array}{r}1 \\
7 \\
7 \\
295\end{array}$ & $\begin{array}{r}1259.6 \\
228.8 \\
7.8 \\
\\
33.9\end{array}$ & $\begin{array}{l}33.2^{* *} \\
6.0^{* *} \\
0.2 \mathrm{NS}\end{array}$ \\
\hline 8 & $\begin{array}{l}\text { Between sexes } \\
\text { Between sires } \\
\text { Sire } \times \text { sex } \\
\text { Interaction } \\
\text { Residual }\end{array}$ & $\begin{array}{r}1 \\
7 \\
7 \\
273\end{array}$ & $\begin{array}{r}922.1 \\
278.5 \\
65.1 \\
\\
73.5\end{array}$ & $\begin{array}{l}12.54 * * \\
3.78^{* *} \\
0.89 \mathrm{NS}\end{array}$ \\
\hline $\begin{array}{r}* * \mathrm{~S} \\
* \mathrm{~S} \\
\mathrm{NS} \mathrm{N}\end{array}$ & $\begin{array}{l}\text { icant at } 1 \text { p. } 10 \\
\text { icant at } 5 \text { p. } 10 \\
\text { ignificant. }\end{array}$ & & & \\
\hline
\end{tabular}


TABLE 2

Analysis of variance of body weight at 6 and 8 weeks of age using sire families for White Plymouth Rock strain Analyse de variance du poids corporel a 6 et 8 semaines d'âge sur les familles de père pour la lignée Plymouth Rock blanche

\begin{tabular}{|c|c|c|c|c|}
\hline $\begin{array}{l}\text { Age in } \\
\text { weeks }\end{array}$ & S.V. & d.f. & Ms. & $\mathrm{F}$ \\
\hline 6 & $\begin{array}{l}\text { Between sexes } \\
\text { Between sires } \\
\text { Sire } \times \text { sex } \\
\text { Interaction } \\
\text { Residual }\end{array}$ & $\begin{array}{r}1 \\
7 \\
7 \\
515\end{array}$ & $\begin{array}{r}975.0 \\
62.7 \\
22.2 \\
\\
19.5\end{array}$ & $\begin{array}{l}50.0^{* *} \\
8.95^{* *} \\
1.14 \mathrm{NS}\end{array}$ \\
\hline 8 & $\begin{array}{l}\text { Between sexes } \\
\text { Between sires } \\
\text { Sire } \times \text { sex } \\
\text { Interaction } \\
\text { Residual }\end{array}$ & $\begin{array}{r}1 \\
7 \\
7 \\
471\end{array}$ & $\begin{array}{r}2477.0 \\
123.3 \\
77.0 \\
\\
81.2\end{array}$ & $\begin{array}{l}30.49 * * \\
1.52 \mathrm{NS} \\
0.95 \mathrm{NS}\end{array}$ \\
\hline
\end{tabular}

** Significant at 1 p. 100 level.

Significant at 5 p. 100 level.

NS Not significant.

TABLE 3

Analysis of variance of body weight at 6 and 8 weeks of age using dams families for Dokkii ${ }_{4}$ strain

Analyse de variance du poids corporel à 6 et 8 semaines d'âge sur les familles de mère pour la lignée Dokki $_{4}$

\begin{tabular}{|c|c|c|c|c|}
\hline $\begin{array}{l}\text { Age in } \\
\text { weeks }\end{array}$ & S.V. & d.f. & Ms. & $\mathbf{F}$ \\
\hline 6 & $\begin{array}{l}\text { Between sexes } \\
\text { Between dams within } \\
\text { sires } \\
\text { Sex } \times \text { dams within } \\
\quad \text { sires } \\
\text { Interaction } \\
\text { Residual }\end{array}$ & $\begin{array}{r}23 \\
23 \\
167\end{array}$ & $\begin{array}{r}299.9 \\
160.4 \\
118.7 \\
35.0\end{array}$ & $\begin{array}{l}8.56^{* *} \\
4.58^{* *} \\
3.39 * *\end{array}$ \\
\hline 8 & $\begin{array}{l}\text { Between sexes } \\
\text { Between dams within } \\
\text { sires } \\
\text { Sex } \times \text { dams within } \\
\quad \text { sires } \\
\text { Interaction } \\
\text { Residual }\end{array}$ & $\begin{array}{r}1 \\
23 \\
23 \\
144\end{array}$ & $\begin{array}{r}787.9 \\
205.4 \\
256.5 \\
72.7\end{array}$ & $\begin{array}{r}10.84^{* *} \\
2.83^{* *} \\
3.53^{* *}\end{array}$ \\
\hline
\end{tabular}

** Significant at 1 p. 100 level.

* Significant at 5 p. 100 level.

NS Not significant. 
Similar results were obtained for white plymouth Rock strain with respect to the effect sex, at 6 and 8 weeks of age. But the variance between sires was highly significant at 6 weeks and not significant at 8 weeks of age. The interaction between sire families and sex, was found to be insignificant, $F$ value being 1.14 and 0.95 (table 2) at 6 and 8 weeks respectively.

\section{Differences between dam families}

In the Dokki, strain (table 3), highly significant differences were observed in both weights at 6 and 8 weeks of age between sexes, dams families within sires and for the dam families within sires $\times$ sex interaction. In White plymouth Rock (table 4) a highly significant difference between sexes was observed at the two ages studied. The analysis of variance showed significant differences between dams within sires $(P<0.05)$ in both ages. The interaction proved to be significant at 6 weeks of age (I.40) at 5 p. IOO level of significance but not at 8 weeks of age ( $F$ value being I.05).

TABLE 4

Analysis of variance of body weight at 6 and 8 weeks of age using dams families for Plymouth Rock strain

Analyse de variance du poids corporel à 6 et 8 semaines d'âge sur les familles de mère pour la lignée Plymouth Rock

\begin{tabular}{|c|c|c|c|c|}
\hline $\begin{array}{l}\text { Age in } \\
\text { weeks }\end{array}$ & S.V. & d.f. & Ms. & F \\
\hline 6 & $\begin{array}{l}\text { Between sexes } \\
\text { Between dams within } \\
\text { sires } \\
\text { Sex } \times \text { dams within } \\
\quad \text { sires } \\
\text { Interaction } \\
\text { Residual }\end{array}$ & $\begin{array}{r}1 \\
54 \\
54 \\
390\end{array}$ & $\begin{array}{r}842.1 \\
48.2 \\
49.6 \\
35.4\end{array}$ & $\begin{array}{l}23.79^{* *} \\
1.36^{*} \\
1.40^{*}\end{array}$ \\
\hline 8 & $\begin{array}{l}\text { Between sexes } \\
\text { Between dams within } \\
\text { sires } \\
\text { Sex } \times \text { dams within } \\
\quad \text { sires } \\
\text { Interaction } \\
\text { Residual }\end{array}$ & $\begin{array}{r}1 \\
53 \\
53 \\
349\end{array}$ & $\begin{array}{r}2825.6 \\
119.9 \\
78.1 \\
74.5\end{array}$ & $\begin{array}{c}37.90^{* *} \\
1.61 \\
1.05\end{array}$ \\
\hline
\end{tabular}

** Significant at 1 p. 100 level.

* Significant at 5 p. 100 level.

NS Not significant. 


\section{GENERAL DISCUSSION AND CONCLUSION}

In general the results showed that sire $\times$ sex interactions were insignificant in all cases, but dam families within sire $\times$ sex interactions showed significance in three cases out of four, the interaction between dam families and sex for plymouth Rock failing to reach significance at 8 weeks of age (table 4 ). The inheritance of sexlinkage in the two strains may perhaps be different, although this cannot be unequivocally proven by the present data. On the other hand, Ayoub and MAGRABY (I975) obtained low heritability estimates of sex differences for the same two strains, which were explained by the mathematical derivation showed by EisEN and LEGATES (I966). Since the genetic variance of the difference between males and females was reported to be twice the genotype $x$ sex interaction, the heritability in the narrow sense of the difference between sexes for the trait can be written as follows :

$$
h^{2}(1-2)=2 \sigma_{G S}^{2} / \sigma_{P(1-2)}^{2}
$$

where $\sigma_{G S}^{2}$ is the additive genotype $\times$ sex interaction variance component, and $\sigma^{2} P_{(1-2)}$ is the phenotypic variance of the differences between sexes for the trait. This derivation assumes that the trait is controlled primarily by additive autosomal genes, and the effect of sex-linkage, dominance and epistasis are not included. Thus the low estimates obtained for $h^{2}(1-2)$ in these two strains may be largely due to the small magnitude of Sire $\times$ Sex interaction as found in the present work. Moreover, the expected genetic progress as shown also by EISEN and LEGATES (rg66) is $\Delta \mathrm{G}(\mathrm{I}-2)=\sqrt{2} i h^{\prime}(1-2) \sigma_{\mathrm{GS}}$.

(Prime notation denotes a Parameter free of scaling effect). One may then conclude according to the results obtained herein of Sire $\times$ Sex interaction, that no great change is expected if selection is based on sire families.

The present study may suggest the need of the development of a method or system of mating to estimate heritability of the difference between sexes for the trait based on the dams component of variance.

Reçu pour publication en juin $19 \% 6$.

\section{ACKNOWLEDGEMENT}

The authors wish to express their deep thanks and gratitude to Dr. M. Khir E1 Din, underSecretary of State-Ministry of Agriculture for his encouragement during the course of this work. Thanks are also due to Dr. A. Mostageer, Faculty of Agriculture, Cairo University for his advice and useful criticism.

\section{RÉSUMÉ}

FACTEURS LIÉS AU SEXE DANS L'HÉRÉDITÉ DES DIFFÉRENCES ENTRE SEXES POUR LE POIDS CORPOREL DANS DEUX LIGNÉES DE POULES

Les interactions sexe $\times$ famille de père et sexe $\times$ famille de mère intra-père ont été étudiées dans deux lignées de poules, Dokki-4 et Plymouth Rock blanche pour le poids corporel à 6 et 
8 semaines d'âge. Les résultats montrent que les interactions sexe $\times$ père ne sont significatives dans aucun cas; par contre l'interaction sexe $\times$ mère intra-père est significative $(P<0,05)$ dans trois cas sur quatre, cette interaction n'atteignant pas le seuil de signification pour la lignée Plymouth Rock à 8 semaines d'âge. L'effet des gènes liés au sexe et les faibles valeurs de l'héritabilité des différences entre sexes sont discutés.

\section{REFERENCES}

Ayoub H., Mérat P., r972. Différences entre familles pour le dimorphisme sexuel du poids à un âge donné chez la Poule. Ann. Génét. Sél. Anim., 4, 45-59.

Ayoub H., Magraby M., r975. Heritability of the differences in body weight between sexes at different ages in two strains of chickens. Ann. Genet. Sel. anim., 7, 299-302.

Beilharz R. C., I960. Research into sex linked control of body weight in poultry and rabbits. Proc. Aust. Soc. Animal Prod. III, 139-146.

Beilharz R. C., I962. A review of the importance of sex-linkage in inheritance. XIIth World's poult. Congress, section papers, I 63-65.

EISEN E. J., Legates J. E., 1966. Genotype-sex interaction and the genetic correlation between the sexes for body weight in Mus Musculus. Genetics. 54, 611-623.

Kinney T. B., Jr., Shoffner R. N., I965. Heritability estimates and genetic correlation among several traits in a meat type poultry population. Poult. Sci., 44, 1020-1032.

Shaklee W. E., Knox C. W., MarSden S. J., 1952. Inheritance of the sex difference of body weight in turkeys. Poultry Sci, 31, 822-825.

Snedecor G. W., Cochran W. G., 1967. Statistical methods, 6e éd. Iowa State College press, Ames, Iowa. 